\title{
Розмірні ознаки ценопопуляцій Polygonum aviculare L. в умовах заплавних лук Кролевецько-Глухівського геоботанічного району
}

\author{
Інна Зубцова \\ Сумський національний аграрний університет, Суми, Україна \\ Адреса для листування: i_zubtsova@ukr.net
}

Отримано: 05.04.19; прийнято до друку: 06.05.19; опубліковано: 28.06.19

\begin{abstract}
Резюме. Представлено результати вивчення розмірних ознак ценопопуляцій Polygonum aviculare L., сформованих у різних місцезростаннях заплавних лук Кролевецько-Глухівського геоботанічного району. Досліджено сім ценопопуляцій Polygonum aviculare, які входять до складу монодомінантних угруповань, провідну роль у формуванні яких відіграє Polygonum aviculare із проективним покриттям у межах 90-95 \%. Досліджувані місцезростання суттєво відрізнялися між собою за ступенем та характером антропогенного впливу: для трьох із них характерні рекреаційні навантаження, для чотирьох інших пасквальні. У процесі роботи використано морфметричний аналіз і комплекс методів статистичноматематичного опрацювання даних. Показано, що реалізація морфологічної мінливості (варіювання значень морфопараметрів рослин у межах однієї популяції) та морфологічної пластичності (зміна середніх значень морфопараметрів при «переході» від популяції до популяції) є невід’ємною складовою комплексу процесів і перетворень, які забезпечують існування ценопопуляцій Polygonum aviculare на теренах досліджуваного регіону. За результатами морфометричного аналізу визначено характерні розмірні ознаки рослин Polygonum aviculare у кожному з місцезростань та ідентифікаційні особливості їхніх модельних особин. Показано, що зміни в розмірі рослин й у їх архітектоніці, що проявляються на тлі антропопресії, мають наслідком суттєві зміни не лише кількісних, але і якісних показників лікарської сировини. Пасквальні навантаження, порівняно з рекреаційними, виявилися більш потужним чинником трансформації морфопараметрів рослин Polygonum aviculare. За результатами проведених досліджень виявлено ценопопуляції, які можуть розглядатися як потенційні осередки регламентованої заготівлі лікарської сировини.

Ключові слова: лікарські рослини, ценопопуляція, морфометричний аналіз, Кролевецько-Глухівский геоботанічний район, Polygonum aviculare.
\end{abstract}

\section{Dimensional Features of Polygonum Aviculare L. Cenopopulations Under the Conditions of Floodplain Meadows of Krolevets-Glukhiv Geobotanical Region}

\section{Inna Zubtsova}

Sumy National Agrarian University, Sumy, Ukraine

Correspondence: i_zubtsova@ukr.net

\begin{abstract}
The article presents the results of the study of the dimensional features of Polygonum aviculare L. cenopopulations formed in different places of floodplain meadows of Krolevets-Glukhiv geobotanical region. We studied seven cenopopulations of Polygonum aviculare, which are part of monodominant communities, the leading role in the formation of which is played by Polygonum aviculare with plant cover in the range of $90-$ $95 \%$. The investigated locations had essential differences in terms of the degree and nature of anthropogenic influence: three of them are of significant recreational loads; the other four are of pasture loads. During the research we used morphometric analysis and a set of methods of statistical and mathematical processing of data. We show that the implementation of morphological variability (variation of morphological parameters of plants
\end{abstract}


within a single population) and morphological plasticity (the change in mean values of morpho-parameters in the «transition» from population to population) is an integral part of the complex of processes and transformations that ensure the existence of cenopopulations of Polygonum aviculare on areas of the studied region. According to the results of morphometric analysis, the specific dimensional features of Polygonum aviculare plants in each of the locations and identifying features of their model individuals were determined. We can say that changes in the size of plants and in their architectonics, which appear at the background of parasitic contamination, are the result of significant changes not only in quantitative but also in qualitative indicators of medicinal raw materials. Pasture loads, in comparison with recreational ones, turned out to be a more powerful factor in the transformation of morpho-parameters of Polygonum aviculare. According to the results of the research, there have been discovered cenopopulations which can be considered as potential centers of regulated gathering of medicinal raw materials.

Key words: medicinal plants, cenopopulations, morphometric analysis, Krolevets-Glukhiv geobotanical region, Polygonum aviculare.

\section{Ветуп}

На сьогодні вивчення розмірних параметрів рослин $\epsilon$ важливою складовою частиною популяційних досліджень $[1,2]$. Проведення такого аналізу, зокрема, дає змогу з'ясувати особливості та закономірності формування габітусу й архітектоніки рослин залежно від еколого-ценотичних умов місцезростань i загалом визначити ступінь їхньої сприятливості для існування певної ценопопуляції $[3,4,5,6,7,8]$. Значущість результатів розмірно-морфометричних досліджень суттєво зростає у випадку, коли вони використовуються як базова основа для встановлення розмірної й особливо віталітетної структури ценопопуляцій [9]. Багаторічні наукові надбання представників Сумської наукової школи популяційної екології рослин доводять, що визначення в складі ценопопуляцій частки рослин різних класів розмірності та (чи) віталітету (життєвості) має не лише теоретичне, а й практичне значення. Дані про зазначені аспекти реагування рослин і їхніх ценопопуляцій на різні типи антропогенних впливів $\epsilon$ важливими під час розробки науково обгрунтованих підходів, спрямованих на забезпечення сталого та невиснажливого використання природних ресурсів [10, 11, 12, 13, 14].

Зазначене вказує на доцільність й актуальність проведення розмірно-морфометричних досліджень для рослин, що належать до групи лікарських. Їх ценопопуляції часто зазнають прямого нерегламентованого антропогенного втручання, яке має наслідком зменшення та навіть повну втрату ресурсного потенціалу видів, які репрезентують цю групу. Відповідно, здійснення такого аналізу є доцільним і для Polygonum aviculare L. - виду, якому притаманна низка цілющих властивостей i значне поширення [15], однак він ще мало охоплений популяційним аналізом. $\mathrm{He} \in$ винятком і ценопопуляції Polygonum aviculare, що зростають на теренах Північно-Східної України й, зокрема, розміщеного в ії межах Кролевецько-Глухівського геоботанічного району.

Цьому регіону та його лучним угіддям притаманне значне багатство рослинного світу $[16,17,18,19] .3$ урахуванням розміщення в його межах значної кількості територій природно-заповідного фонду, у т. ч. й найбільшої в Сумській області природоохоронної установи - регіонального ландшафтного парку «Сеймський» площею 98 857,9 га та активним формуванням об'єднаних територіальних громад, перспективними планами розвитку яких не виключається реалізація бізнеспроектів із заготівлі й реалізації лікарської сировини, проведення в цьому регіоні досліджень, спрямованих на вивчення ценопопуляцій найбільш поширених лікарських рослин стає особливо необхідним.

Мета статті - оцінити розмірні характеристики рослин, представлених у складі ценопопуляцій Polygonum aviculare в умовах заплавних лук Кролевецько-Глухівского геоботанічного району.

\section{Матеріали й методи}

Дослідженнями було охоплено сім ценопопуляцій Polygonum aviculare, які зростають на заплавних луках КролевецьГлухівського геоботанічного району. Усі вони входять до складу монодомінантних угруповань, провідну роль у формуванні яких відіграє саме Polygonum aviculare iз проективним покриттям у межах 90-95\%. Для інших видів, репрезентованих у досліджуваних фітоценозах, цей показник не перевищує $2 \%$. Місцязростання угруповань суттєво відрізнялися між собою за ступенем та характером антропогенного впливу: для трьох iз них характерні рекреаційні навантаження, для чотирьох інших - пасквальні (табл. 1). 
Узагальнена інформація про місцезростання досліджуваних ценопопуляцій

\begin{tabular}{|c|c|c|c|}
\hline $\begin{array}{c}\text { № та умовне } \\
\text { позначення } \\
\text { ценопопуляції }\end{array}$ & Угруповання & $\begin{array}{c}\text { Вид антропогенних } \\
\text { навантажень }\end{array}$ & $\begin{array}{c}\text { Ступінь } \\
\text { антропогенного } \\
\text { впливу }\end{array}$ \\
\hline$\Pi 1$ & Polygonum aviculare subpurum & Рекреаційні & 1 особа/год./га \\
\hline$\Pi 2$ & Polygonum aviculare subpurum & Рекреаційні & 3 особи/год./га \\
\hline$\Pi 3$ & Polygonum aviculare subpurum & Рекреаційні & 12 осіб/год./га \\
\hline$\Pi 4$ & Polygonum aviculare subpurum & Пасквальні & 2 шт. ВРХ/га \\
\hline$\Pi 5$ & Polygonum aviculare subpurum & Пасквальні & 3 шт. ВРХ/га \\
\hline$\Pi 6$ & Polygonum aviculare subpurum & Пасквальні & 4 шт. ВРХ/га \\
\hline$\Pi 7$ & Polygonum aviculare subpurum & Пасквальні & 5 шт. ВРХ/га \\
\hline
\end{tabular}

Із метою оцінки розмірних параметрів рослин Polygonum aviculare застосовано морфометричний аналіз. При цьому в досліджуваних фітоценозах за випадковою схемою відбирали 25-30 рослин генеративного онтогенетичного стану. У них оцінювали величини 13 статичних метричних та 7 ста- тичних алометричних показників (табл. 2, 3). Для оцінки статистичної достовірності отриманих кількісних даних та їх узагальнення застосовували точкове оцінювання й дисперсійний аналіз [23]. Це забезпечувалося використанням статистичних комп'ютерних пакетів STATISTICA та PAST.

Таблиия 2

Перелік статичних метричних морфопараметрів, використаних для оцінки стану рослин Polygonum aviculare

\begin{tabular}{|c|c|c|}
\hline Назва морфопараметра & Умовні позначення $^{1}$ & Одиниця виміру \\
\hline Загальна маса рослини & $\mathrm{W}$ & $\Gamma$ \\
\hline Загальна маса вегетативних органів & Wveg & $\Gamma$ \\
\hline Загальна фітомаса листків & WL & $\Gamma$ \\
\hline Фітомаса стебла & Wst & $\Gamma$ \\
\hline Фітомаса одного листка & WL_1 & $\Gamma$ \\
\hline Загальна площа поверхні листків & A & $\mathrm{cm}^{2}$ \\
\hline Загальна кількість листків & NL & шт. \\
\hline Кількість бічних пагонів першого порядку & $\mathrm{B}$ & шт. \\
\hline Довжина головного пагона & $\mathrm{L}$ & $\mathrm{cm}$ \\
\hline Діаметр стебла & $\mathrm{D}$ & cM \\
\hline Загальна маса репродуктивних органів & Wgen & $\Gamma$ \\
\hline Маса одного репродуктивного органа & Wgen1 & $\Gamma$ \\
\hline Загальна кількість генеративних органів & Ngen & шт. \\
\hline
\end{tabular}

Примітка. тут і в табл. 2 умовні позначення та розрахункові формули подано за вою [20], Р. Хантом [21], Ю. А. Злобіним [22] із доповненнями автора.

Таблиия 3

Перелік статичних алометричних морфопараметрів, використаних для оцінки стану рослин Polygonum aviculare

\begin{tabular}{|c|c|c|}
\hline Назва морфопараметра & $\begin{array}{c}\text { Умовні позначення та розрахункові } \\
\text { формули морфопараметрів }\end{array}$ & Одиниця виміру \\
\hline Площа листків на одиницю фітомаси & $\mathrm{LAR}=\mathrm{A} / \mathrm{W}$ & $\mathrm{cm}^{2} / \Gamma$ \\
\hline Фотосинтетичне зусилля & $\mathrm{LWR}=\mathrm{WL} / \mathrm{W}$ & $\mathrm{\Gamma} / \Gamma$ \\
\hline Відносний приріст & $\mathrm{HWR}=\mathrm{L} / \mathrm{W}$ & $\mathrm{cm} / \Gamma$ \\
\hline $\begin{array}{c}\text { Відношення загальної площі листків до діаметра } \\
\text { стебла }\end{array}$ & $\mathrm{ADR}=\mathrm{A} / \mathrm{D}$ & $\mathrm{cm} / \mathrm{Mm}$ \\
\hline $\begin{array}{c}\text { Співвідношення між довжиною головного } \\
\text { пагона та діаметром стебла }\end{array}$ & $\mathrm{HDR}=\mathrm{L} / \mathrm{D}$ & $\mathrm{cm} / \mathrm{cm}$ \\
\hline Репродуктивне зусилля & $\mathrm{RE} 1=(\mathrm{Wgen} / \mathrm{W}) \times 100$ & $\%$ \\
\cline { 2 - 3 } & $\mathrm{RE} 2=($ Wgen $/ \mathrm{A}) \times 100$ & $\%$ \\
\hline
\end{tabular}


Розмірні ознаки иенопопуляцій Polygonum aviculare L. в умовах заплавних лук КролевецькоГлухівського геоботанічного району

\section{Результати дослідження та їх обговорення}

Результати оцінки розмірних величин рослин Polygonum aviculare наведено в табл. 4. Вони засвідчують, що в кожному 3 місцезростань формуються особини зі специфічним комплексом значень провідних морфопараметрів. Для абсолютної більшості розмірних величин зареєстровані відмінності у величинах морфопараметрів у рослин із різних угруповань $є$ статистично достовірними (табл. 5). Винятком є лише показники загальної маси вегетативних органів, кількості бічних пагонів і репродуктивного зусилля (RE1).

Усі морфопараметри демонструють свої особливості щодо змін величин за досліджуваними фітоценозами (рис. 1). Це вказує, що кожен із розмірних показників відіграє специфічну роль під час формування комплексу морфологічних адаптацій у рослин Polygonum aviculare до умов конкретних місцезростань.

Водночас їм притаманний і прояв певних загальних тенденцій. Так, найбільші значення восьми морфопараметрів (iз 20 оцінених) зареєстровані в першій ценопопуляції. Найбільші показники ще чотирьох припадають на ценопопуляцію № 4. Тобто максимальні значення більшості розмірних показників відповідають місцезростанням, які зазнають найменш інтенсивних рекреаційних i пасквальних впливів. Навпаки, найменші значення провідних морфопараметрів здебільшого реєструються в ценопуляції № 7, яка існує в умовах найбільш інтенсивного випасання худоби.

Загалом результати проведених досліджень засвідчують, що існування рослини й ценопопуляції Polygonum aviculare супроводжується активною реалізацією ними морфологічної пластичності [22], ознакою якої $\epsilon$ наявність відмінностей середніх значень морфопараметрів за різними угрупованнями, так і морфологічної мінливості (проявляється у варіюванні абсолютних значень розмірних характеристик у межах конкретного фітоценозу). Факт реалізації морфологічної мінливості, зокрема, наочно доводять значення похибки середнього арифметичного, наведені в табл. 4.

Одним із результатів прояву як морфологічної мінливості, так і морфологічної пластичності, $є$ формування в кожному 3 місцезростань рослин зі специфічною морфологічною структурою. Морфограми, представлені на рис. 2, наприклад, наочно демонструють:
Таблиия 4

Значення довірчого рівня для морфометричних параметрів рослин Polygonum aviculare із різних місцезростань

\begin{tabular}{|c|c|}
\hline Морфопараметр & $\begin{array}{c}\text { Значення довірчого } \\
\text { рівня, } \boldsymbol{p}^{\text {I }}\end{array}$ \\
\hline W & $0,00000^{*}$ \\
\hline W veg & 0,81387 \\
\hline WL & $0,00000^{*}$ \\
\hline W st & $0,00433^{*}$ \\
\hline WL_1 & $0,00000^{*}$ \\
\hline A & $0,04008^{*}$ \\
\hline NL & $0,00000^{*}$ \\
\hline B & 0,24327 \\
\hline L & $0,00012^{*}$ \\
\hline D & $0,00000^{*}$ \\
\hline Wen & $0,00003^{*}$ \\
\hline W gen 1 & $0,00118^{*}$ \\
\hline LAR & $0,01087^{*}$ \\
\hline LWR & $0,01349^{*}$ \\
\hline HWR & $0,00000^{*}$ \\
\hline ADR & $0,00000^{*}$ \\
\hline HDR & $0,00028^{*}$ \\
\hline RE1 & $0,00003^{*}$ \\
\hline RE2 & 0,26422 \\
\hline & $0,00090^{*}$ \\
\hline
\end{tabular}

Примітка. Позначкою «*» відзначено відмінності, що є статистично достовірними на рівні $95 \%$ і вище.

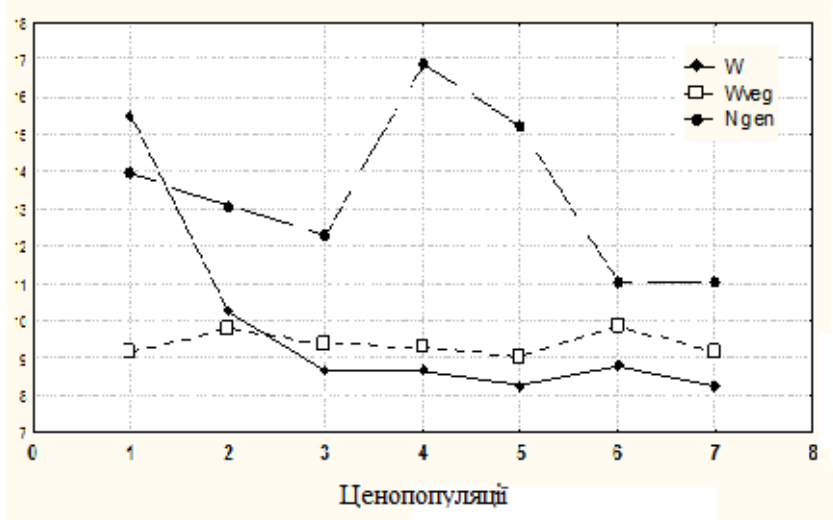

Рис. 1. Зміна величин середніх значень морфопараметрів у рослин ценопопуляиій

Polygonum aviculare за досліджуваними місиезростаннями (нумерація ценопопуляцій відповідає наведеній у табл. 1)

відмінною особливістю рослин із ценопопуляції №1 $\epsilon$ їх великий розмір. Значення низки морфопараметрів у них $\epsilon$ більшими, ніж у рослин з інших місцезростань. Разом із тим рослини 3 цієї ценопопуляції вирізняються відносно невисокими показниками маси стебла. 
Науковий вісник Східноєвропейського національного університету імені Лесі Українки. Серія: Біологічні науки, 2019, 3 (387)

Таблиияя 5

Морфометричні параметри рослин Polygonum aviculare в різних ценопопуляціях

\begin{tabular}{|c|c|c|c|c|c|c|c|}
\hline \multirow{4}{*}{$\begin{array}{c}\text { Морфо- } \\
\text { пара- } \\
\text { метр }\end{array}$} & \multicolumn{7}{|c|}{ Умовні позначення ценопопуляцій } \\
\hline & ПI & $\Pi 2$ & \begin{tabular}{l|l}
$\Pi 3$ & \\
\end{tabular} & \begin{tabular}{l|l}
$\Pi 44$ & \\
\end{tabular} & $\Pi 5$ & П6 & $\Pi 7$ \\
\hline & $\overline{\mathrm{X}} \pm S_{\bar{x}}$ & $\overline{\mathrm{X}} \pm S_{\bar{x}}$ & $\overline{\mathrm{X}} \pm S_{\bar{x}}$ & $\overline{\mathrm{X}} \pm S_{\bar{x}}$ & $\overline{\mathrm{X}} \pm S_{\bar{x}}$ & $\overline{\mathrm{X}} \pm S_{\bar{x}}$ & $\overline{\mathrm{X}} \pm S_{\bar{x}}$ \\
\hline & \multicolumn{7}{|c|}{ статичні метричні морфопараметри } \\
\hline $\mathrm{W}$ & $15,51 \pm 1,431$ & $10,25 \pm 0,353$ & $8,66 \pm 0,251$ & $8,64 \pm 0,261$ & $8,28 \pm 0,287$ & $8,78 \pm 0,336$ & $8,24 \pm 0,266$ \\
\hline W veg & & $9,79 \pm 0,367$ & $9,36 \pm 0,216$ & & & & \\
\hline WL & $3,18 \pm 0,46$ & $2,87 \pm 0,256$ & $2,30 \pm 0,287$ & $2,23 \pm 0,2$ & $0,88 \pm 0,146$ & $0,70 \pm 0$ & $0,64 \pm 0,119$ \\
\hline W st & $3,51 \pm 0,233$ & $5,04 \pm 0,208$ & $5,92 \pm 0,337$ & $5,89 \pm 0,398$ & $5,34 \pm 1,434$ & $7,90 \pm 0$ & $7,39 \pm 0$ \\
\hline WL_1 & $16 \pm 0,023$ & $0,15 \pm 0,009$ & $0,15 \pm 0,020$ & $0,13 \pm 0$ & $0,07 \pm 0,014$ & $0,05 \pm 0$ & $0,04 \pm 0,007$ \\
\hline $\mathrm{A}$ & $40 \pm 7,589$ & & $43,00 \pm 3,838$ & $47,4 \pm 2,756$ & $36,20 \pm 2,204$ & & $45,26 \pm 2,134$ \\
\hline NL & $22,33 \pm 2,672$ & $20,13 \pm 0,899$ & $16,00 \pm 0,985$ & $17,26 \pm 0,538$ & $12,33 \pm 0,721$ & $13,66 \pm 0,784$ & $15,93 \pm 0,581$ \\
\hline $\mathrm{B}$ & $3,80 \pm 0,626$ & $2,66 \pm 0,484$ & $2,66 \pm 0,443$ & $3,13 \pm 0,290$ & $2,73 \pm 0,206$ & $3,60 \pm 0$ & $2,73 \pm 0$ \\
\hline $\mathrm{L}$ & $4,00 \pm 2,122$ & $19,66 \pm 1,240$ & $21,06 \pm 1,274$ & $25,86 \pm 1,103$ & $20,13 \pm 0,638$ & $24,60 \pm 0$ & $22,53 \pm 0,975$ \\
\hline $\mathrm{D}$ & $40 \pm 0,040$ & $0,26 \pm 0,031$ & $0,20 \pm 0$ & $0,21 \pm 0$ & $0,13 \pm 0,021$ & $0,24 \pm 0$ & $0,19 \pm 0,019$ \\
\hline W gen & $66 \pm 0,128$ & & & 60 & 47 & $0,17 \pm 0$ & $0,20 \pm 0$ \\
\hline W gen 1 & $04 \pm 0,007$ & & $03 \pm 0,005$ & $0,03 \pm 0$, & $0,02 \pm 0,002$ & $0,01 \pm 0$ & $0,01 \pm 0,002$ \\
\hline \multirow[t]{2}{*}{$\mathrm{N}$ gen } & $13,93 \pm 2,721$ & $13,05 \pm 1,770$ & $12,26 \pm 1,685$ & $16,86 \pm 1,290$ & $15,20 \pm 0,921$ & $11,06 \pm 0,813$ & $11,40 \pm 0,741$ \\
\hline & \multicolumn{7}{|c|}{ статичні алометричні морфопараметри } \\
\hline & $3,64 \pm 2,721$ & $5,02 \pm 0,641$ & & $5,57 \pm 0,457$ & $4,36 \pm 0,27$ & $4,72 \pm 0,346$ & $5,54 \pm 0,288$ \\
\hline LWR & $0,20 \pm 0,287$ & $0,33 \pm 0,019$ & $0,26 \pm 0,033$ & $0,25 \pm 0,0$ & $0,10 \pm 0,016$ & $0,07 \pm 0,01$ & $0,07 \pm 0,014$ \\
\hline HWR & $1,56 \pm 0,023$ & $2,10 \pm 0,077$ & $2,37 \pm 0,115$ & $2,98 \pm 0,171$ & $2,38 \pm 0,086$ & $2,78 \pm 0,122$ & $2,78 \pm 0,163$ \\
\hline ADR & $153,26 \pm 0,06$ & $162,80 \pm 11,79$ & $240,7 \pm 30,27$ & $263,53 \pm 30,4$ & $331,13 \pm 37,69$ & $210,88 \pm 31,5$ & $263,22 \pm 31,04$ \\
\hline HDR & $64,40 \pm 19,29$ & $74,55 \pm 5,735$ & $138,06 \pm 22,3$ & $151,53 \pm 21,87$ & $186,53 \pm 19,9$ & $130,33 \pm 21,1$ & $133,77 \pm 16,1$ \\
\hline RE1 & $3,75 \pm 6,346$ & $3,30 \pm 0,765$ & $12,18+7,878$ & $6,04 \pm 0,887$ & $4,57 \pm 0,558$ & $2,01 \pm 0,244$ & $2,64 \pm 0,413$ \\
\hline RE2 & $1,02 \pm 0,633$ & $0,60 \pm 0,132$ & $1,29 \pm 0,267$ & $1,06 \pm 0,155$ & $1,12 \pm 0,181$ & $0,47 \pm 0,061$ & $0,47 \pm 0,076$ \\
\hline
\end{tabular}

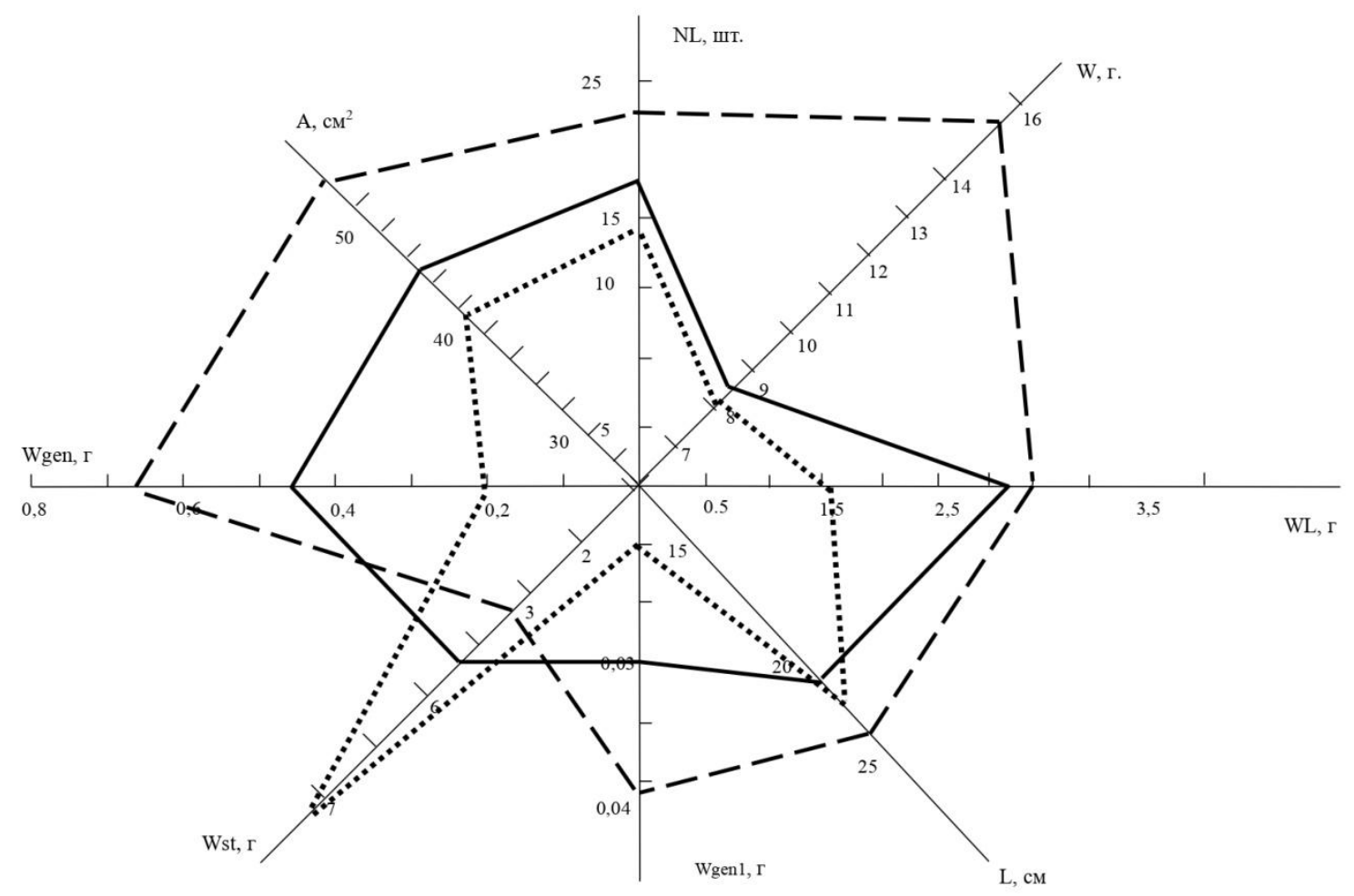

Рис. 2. Морфограми рослин Polygonum aviculare із різних цеенопопуляцій, побудовані на основі результатів оцінки величин статичних метричних морфопараметрів (ї умовні позначення відповідають наведеним у табл. 2 ma 3). На рисунку зображено такі ценопопуляції: 
Розмірні ознаки ценопопулячій Polygonum aviculare L. в умовах заплавних лук КролевецькоГлухівського геоботанічного району

Суттєві антропогенні впливи мають наслідком не тільки загальне здрібнення особин Polygonum aviculare, a й прояв у їх архітектоніці своєрідних особливостей. У ценопопуляції № 7 на тлі пасквальних навантажень відбулась активізація формування пагонів, що проявилося як у збільшенні маси стебла, так і його довжини. Загалом, випас, порівняно 3 рекреаційним тиском, проявляе більшу силу впливу на значення розмірних величин рослин Polygonum aviculare. Так, для пасквальних навантажень значення цієї характеристики здебільшого варіюють у межах $34,1-76,8 \%$, а для рекреаційних - 16,2-53,5\%.

\section{Висновки}

Морфологічні адаптації $\epsilon$ важливою складовою комплексу заходів, які реалізуються на рівні рослин та ценопопуляцій Polygonum aviculare при їх пристосуванні до умов місцезростань загалом та до певних типів антропогенних навантажень. Зміни в розмірі рослин i в їx архітектоніці (наприклад збільшення відносних та абсолютних показників, пов'язаних із масою стебел або ж, навпаки, зменшення аналогічних показників, пов'язаних із масою листків), що проявляються на тлі антропопресії, мають наслідком суттєві зміни не лише кількісних, але і якісних показників лікарської сировини. Пасквальні навантаження, порівняно 3 рекреаційними, виявилися більш потужним чинником трансформації морфопараметрів рослин Polygonum aviculare. Виходячи 3 результатів розмірно-морфометричних досліджень, як потенційні осередки регламентованої заготівлі лікарської сировини можуть розглядатися популяції № 1 та 2, що зростають на фоні незначного рекреаційного впливу. Рослини, представлені в їхньому складі, $\epsilon$ одними 3 найбільших за розміром та мають досить добре розвинену листкову поверхню, а самі популяції вирізняються одними 3 найвищих показників популяційної щільності $53,3-54,8$ особин $/ \mathrm{m}^{2}$ проти $34,8-43,2$ особин/ $\mathrm{m}^{2}$ на територіях із випасом.

\section{Література}

1. Злобін, Ю. А.; Скляр, В. Г.; Бондарєва, Л. М.; Кирильчук, К. С. Концепція морфометрії у сучасній ботаніці. Чорноморський ботанічний журнал; 2009, 1, с 5-22.

2. Злобин, Ю. А. Популяционная экология растений: современное состояние, точки роста; Университет. кн.: Сумы, 2009; с 263.
3. Скляр, В. Г. Розмірна структура деревостанів сосни звичайної в лісах НовгородСіверського Полісся. Ученые записки Таврического национального университета им. В. И. Вернадского. Серия «Биология, химия»; 2011, 4, с 292-302.

4. Скляр, В. Г. Морфологічні ознаки проростків дуба звичайного в різних екологоценотичних умовах Новгород-Сіверського Полісся. Вісник Запорізького національного університету. Біологічні науки; 2011, 2, с 119-125.

5. Скляр, В. Г. Морфологічні параметри дрібного підросту клена гостролистого в лісах Новгород-Сіверського Полісся. Вісник Дніпропетровського університету. Біологія. Екологія; 2012, 20, с 100-106.

6. Шерстюк, М. Ю. Морфометричні ознаки Oxycoccus palustris Pers. у болотних та лісоболотних фітоценозах Українського Полісся. Науковий вісник Східноєвропейського наиіонального університету імені Лесі Українки; 2016, 7, с 78-83.

7. Скляр, Ю. Л. Ростові ознаки Potamogeton natans L. у різних еколого-ценотичних умовах водойм басейну Десни. Науковий вісник Східноєвропейського національного університету імені Лесі Украӥнки; 2017, 7, c.47-55.

8. Скляр, В. Г. Розмірна структура підросту Acer platanoides L. в лісових фітоценозах Лівобережного Полісся України. Вісник Львівського університету. Серія біологічна; 2015, 70, с 138-143.

9. Злобин, Ю. А.; Скляр, В. Г.; Клименко, А. А. Популяции редких видов растений: теоретические основы и методика изучения. Университетская книга: Сумы, 2013; с 439.

10. Злобин, Ю. А.; Кирильчук, К. С. Популяционная структура пойменных луговых фитоценозов. Известия Гомельского государственного университета имени Ф. Скорины; 2005, 6, с 65-70.

11. Бондарєва, Л. М.; Бєлан, С. С. Порівняльний аналіз віталітетної структури популяцій ценозоутворюючих злаків на територіях заказників заплави річки Сули та на ділянках із антропогенним використанням. Вісник Сумського національного аграрного університету; 2010, 4, с 15-21.

12. Кирильчук, К. С.; Баштовий, М. Г. Комплексний аналіз популяцій Trifolium pratense L. на заплавних луках лісостепової зони України. Науковий вісник Східноєвропейського начіонального університету імені Лесі Украӥнки; 2018, 4, с 5-15.

13. Баштовий, М. Г. Популяційний моніторинг та функціональне зонування лісових рекреаційних екосистем як об'єктів зеленого туризму. Вісник Сумського наиіонального аграрного університету; 2007, 10-11, c 201-204.

14. Тихонова, О. М.; Скляр, В. Г.; Коровякова, Т. О. Популяційний аналіз та його використання у процесі регулювання забур'яненості агрофітоценозів. Вісник Черкаського університету: серія «Біологічні науки»; 2016, 2, с 99-107.

15. Зубцова, I. В. Онтогенетична структура ценопопуляцій Polygonum aviculare L. в умовах Кролевецько-Глухівського геоботанічного району. 
Науковий вісник Східноєвропейського начіонального університету імені Лесі Українки. Серія: Біологічні науки; 2016, 12, с 30-36.

16. Козир, М. С. Геоботанічна характеристика заплавних лук нижньої течії р. Сейм. Український ботанічний журнал; 2008, 5, с 656-665.

17. Козир, М. С. Рослинність заплавних лук p. Сейм (синтаксономія, динаміка, охорона). Автореф. дис. канд. біол. наук: спец. 03.00.05. Київ, Ін-т. ботаніки ім. М. Г. Холодного НАН України, 2013, с 18

18. Козир, М. С. Раритетні угруповання заплави річки Сейм. Проблемы и перспективы исследований растительного мира, Материаль междунар. науч. практ. конф. молодых учених, 13-16 мая 2014 г. Ялта, с 10.
19. Заповідні скарби Сумщини; Андрієнко, Т. Л. Ред.; Вид-во «Джерело»: Суми, 2001; с 208.

20. Карманова, И. В. Математические методы изучения роста и продуктивности растений. Наука: Москва, 1976; с 222.

21. Hunt R. Plant growth analysis. Arnold: London, 1978; p 67.

22. Злобин, Ю. А. Принциипь $и$ методы изучения иенотических популяций растений. Изд-во Казанского ун-та: Казань, 1989; с 146.

23. Царенко, О. М.; Злобін, Ю. А.; Скляр, В. Г.; Панченко, С. М. Комп'ютерні методи в сільському господарстві та біології. Університет. кн.: Суми, 2000; c 203. 